Article

\title{
Genetic Parameters and Genome-Wide Association Studies for Anti-Müllerian Hormone Levels and Antral Follicle Populations Measured After Estrus Synchronization in Nellore Cattle
}

\author{
Laís Grigoletto ${ }^{1,2, *(\mathbb{D}}$, Miguel Henrique Almeida Santana ${ }^{2}$, Fabiana Fernandes Bressan ${ }^{2}(\mathbb{D}$, \\ Joanir Pereira Eler ${ }^{2}$, Marcelo Fábio Gouveia Nogueira ${ }^{3}{ }^{(0)}$, Haja N. Kadarmideen ${ }^{4}(\mathbb{D}$, \\ Pietro Sampaio Baruselli ${ }^{5}$, José Bento Sterman Ferraz ${ }^{2}$ (D) and Luiz F. Brito ${ }^{1, *(D)}$ \\ 1 Department of Animal Sciences, Purdue University, West Lafayette, IN 47907, USA \\ 2 Department of Veterinary Medicine, College of Animal Science and Food Engineering, University of São \\ Paulo, Pirassununga, 13635-900 São Paulo, Brazil; miguel-has@hotmail.com (M.H.A.S.); \\ fabianabressan@usp.br (F.F.B.); joapeler@usp.br (J.P.E.); jbferraz@usp.br (J.B.S.F.) \\ 3 Department of Biological Sciences, School of Sciences and Languages, São Paulo State University, Assis, \\ 19806-900 São Paulo, Brazil; marcelo.fabio@unesp.br \\ 4 Department of Applied Mathematics and Computer Science, Technical University of Denmark, \\ 102500 Lyngby, Denmark; hajak@dtu.dk \\ 5 College of Veterinary Medicine and Animal Science, University of Sao Paulo, 05508-270 São Paulo, Brazil; \\ pietro.baruselli@gmail.com \\ * Correspondence: lgrigoletto@usp.br (L.G.); britol@purdue.edu (L.F.B.)
}

Received: 1 June 2020; Accepted: 10 July 2020; Published: 13 July 2020

Simple Summary: Reproductive performance has direct economic implications on the beef cattle industry. The majority of Zebu breeds (e.g., Nellore; Bos taurus indicus) have poor reproductive performance compared to other cattle breeds. In this context, genetic progress can be achieved for fertility and reproduction through the use of genomic selection for indicator variables that efficiently assess the biological mechanisms underlying cattle fertility. Therefore, this study aimed to estimate genetic parameters (heritability and genetic correlations) and identify candidate genes associated with anti-Müllerian hormone levels (AMH) and antral follicle populations measured after estrous synchronization (AFP) in Nellore cattle. Our findings indicate that measuring circulating AMH in Nellore cattle enables the identification of animals with high genetic merit for superovulatory responses, as well as early selection of the best oocyte donors for in vitro embryo production. Both traits are heritable and influenced by a large number of important genes. Therefore, AMH and AFP can be used as indicator traits to genetically improve fertility rates in Nellore cattle and to identify better oocyte donors.

Abstract: Reproductive efficiency plays a major role in the long-term sustainability of livestock industries and can be improved through genetic and genomic selection. This study aimed to estimate genetic parameters (heritability and genetic correlation) and identify genomic regions and candidate genes associated with anti-Müllerian hormone levels (AMH) and antral follicle populations measured after estrous synchronization (AFP) in Nellore cattle. The datasets included phenotypic records for 1099 and 289 Nellore females for AFP and AMH, respectively, high-density single nucleotide polymorphism (SNP) genotypes for 944 animals, and 4129 individuals in the pedigree. The heritability estimates for AMH and AFP were $0.28 \pm 0.07$ and $0.30 \pm 0.09$, and the traits were highly and positively genetically correlated $\left(r_{G}=0.81 \pm 0.02\right)$. These findings indicated that these traits can be improved through selective breeding, and substantial indirect genetic gains are expected by selecting for only one of the two traits. A total of 31 genomic regions were shown to be associated with AMH or AFP, and two genomic regions located on BTA1 (64.9-65.0 Mb and 109.1-109.2 Mb) overlapped between 
the traits. Various candidate genes were identified to be potentially linked to important biological processes such as ovulation, tissue remodeling, and the immune system. Our findings support the use of AMH and AFP as indicator traits to genetically improve fertility rates in Nellore cattle and identify better oocyte donors.

Keywords: anti-Müllerian; biomarker; fertility rate; indicine; GWAS; heritability; ovarian reserve; reproduction; Zebu

\section{Introduction}

Reproductive performance directly impacts the profitability of the beef cattle industry $[1,2]$. Precocity and fertility rates are lower in Zebu cattle (Bos taurus indicus) compared to Taurine breeds (Bos taurus taurus) [3]. The majority of beef cattle breeding programs focus on growth and carcass traits, which are usually easier to measure in comparison with female reproductive traits [4]. Furthermore, most reproductive traits have low to moderate heritability estimates, therefore, reduced genetic progress is usually attained per time unit [5,6]. Despite the high environmental influence on reproductive traits (i.e., low to moderate heritability estimates), there is enough genetic variability to enable genetic progress through direct selection $[7,8]$. Therefore, identifying novel phenotypes that better represent the biological mechanisms underlying reproductive performance could be of great value to beef cattle breeding programs, especially in Zebu cattle breeds raised in tropical conditions.

Anti-Müllerian hormone $(\mathrm{AMH})$ regulates follicle selection [9], as well as antral follicle population (AFP) [10]. AMH is strongly associated with the ovarian response and embryo scores [11], and therefore in vitro fertilization [12]. In vitro fertilization and cattle embryo production are common practices in beef cattle production systems, especially in Zebu breeds [13-15]. The measurement of AMH concentration and its association with reproductive and fertility traits were widely studied in livestock, including cattle [16-21]. These studies indicated that circulating AMH levels are a useful indicator of fertility and reproductive performance. The role of AMH in different aspects of reproductive physiology is noteworthy, and it is involved with AFP [16,22], superovulation responses [23], in vitro embryo production [10,24,25], fertility traits (i.e., age at puberty and postpartum interval) [26], and longevity [27] in beef cattle. The definition and use of efficient biological indicators of fertility is a promising path to increase the success of reproductive technologies (e.g., embryo transfer, superovulatory responses), especially in Nellore cattle raised in tropical conditions.

Genome-wide association studies (GWAS) are frequently used in livestock studies aiming to detect causal mutations and candidate genes associated with traits of interest [28-31]. In this context, knowledge regarding the genomic regions, candidate genes, and metabolic pathways related to reproductive physiology and fertility indicators is paramount to the optimization of genomic selection to improve female reproductive efficiency [32,33]. In Holstein cattle, genomic regions associated with AMH levels were previously linked with fertility, superovulatory responses, and embryo development $[20,34]$. However, this is currently underexplored in Zebu cattle. The main objectives of this study were to estimate the genetic parameters for AMH and AFP using genomic information and to identify genomic regions, candidate genes, and metabolic pathways related to AMH and AFP traits in Nellore cattle using a high-density single nucleotide polymorphism (SNP) chip panel.

\section{Methods}

\subsection{Ethical Statement}

No approval from the local Ethics Committee was required for this study because the datasets were generated in previous experiments approved by the Bioethics Commission of the School of Veterinary Medicine and Animal Sciences of the University of Sao Paulo, Sao Paulo, Brazil [35,36]. 


\subsection{Animals and Phenotypic Data}

The datasets used were from three commercial beef cattle farms (Segredo, Engano, and CFM) located in the state of Mato Grosso do Sul in the midwestern region of Brazil. All animals were raised under similar environmental conditions and received mineral supplementation on a pasture-based production system, with ad libitum water. The pedigree dataset included 4129 animals (2601 females and 1528 males), in which 1032 were founders and 2883 individuals had both parents known. The pedigree spanned up to five generations according to suggestions that the inclusion of at least three generations is enough to predict accurate breeding values and estimate genetic parameters [37]. Furthermore, as genomic information was used, the relationships from more distant ancestors were also captured. All animals were from the same breeding program and were genetically related, as there was exchange of semen and breeding animals across the three farms. The average pedigree and genomic inbreeding coefficients were 0.008 and 0.010 , respectively.

A total of 1099 females 425 (cows (16 months of age) and 674 heifers (14 months of age)) were measured for AFP. The total number of visible follicles ( $\geq 3 \mathrm{~mm}$ in diameter) in both ovaries were evaluated using ultrasonography equipment (7.5 MHz transrectal linear transducer, Mindray M5Vet; Mindray, Mahwah, NJ, USA). Animals were recorded at the beginning of the follicular wave (day 4 of the synchronization protocol after applying a progesterone intravaginal device, plus $2 \mathrm{mg}$ of estradiol benzoate on day 0) [24]. The synchronization protocol was used to ensure that all the animals were measured at a similar reproductive stage, thereby reducing environmental influence on trait expression. Blood samples of 289 Nellore heifers were collected using vacuum tubes containing ethylenediamine tetraacetic acid-EDTA (Health Co, Canton, MA, USA) via jugular vein puncture to measure AMH concentrations. These heifers were, on average, $14.10 \pm 0.03$ months old, and all of them had AFP records. The AMH assay was conducted at the IgAc Laboratory (Institute Genese of Scientific Analyses, São Paulo, SP, Brazil) using the Bovine AMH enzyme-linked immunosorbent assay AL-114 kit (Ansh Labs, Webster, TX, USA), following the protocol described by Batista et al. [35].

\subsection{Genotypic Quality Control}

A total of 944 females (379 cows and 565 heifers) were genotyped using a high-density SNP chip panel (Illumina Inc., San Diego, CA, USA) containing 777,962 single nucleotide polymorphisms (SNP). Quality control was performed using the PREGSF90 program [38]. The following criteria were used for the exclusion of SNPs: minor allele frequency (MAF), SNP call rate, and animal call rate lower than 0.05, 0.90, and 0.90, respectively, extreme deviation (greater than 0.15) from the Hardy-Weinberg equilibrium, defined as the difference between the observed and expected frequency of heterozygotes [39], and markers located on the sex chromosomes or mitochondrial DNA. A total of 467,209 SNPs was found to be distributed across 29 autosomal chromosomes, and 917 samples remained for further analyses.

\subsection{Statistical Analyses}

\subsubsection{Variance Components, Genetic Parameters, and Breeding Value Prediction}

A linear animal model and the Average Information Restricted Maximum Likelihood method (AI-REML) were used to estimate variance components, heritability, and genetic correlations using the AIREMLF90 package from the BLUPF90 software [40,41]. Genomic breeding values for both traits (AMH and AFP) were directly predicted using the single-step Genomic Best Linear Unbiased Predictor (ssGBLUP) procedure. A bivariate animal model was fitted as follows:

$$
\mathbf{y}=\mathbf{X} \beta+\mathrm{Z} \alpha+\mathbf{e}
$$

where $\mathbf{y}$ is the vector of individual observations for AMH and AFP, $\beta$ is the vector associated with the fixed effect of contemporary group and the linear effect of age of the animal at the measurement, $\alpha$ is the vector of direct additive genetic effects, $\mathbf{X}$ and $\mathbf{Z}$ are the incidence matrices linking records 
to the $\beta$ and $\alpha$ vectors, respectively, and $\mathbf{e}$ is the vector of the residual effects. The contemporary group was defined by concatenating the effects of the farm (3 levels), management group, birth year (2013-2017), and season of the year during which the measurement was taken. Additive genetic and residual effects were assumed to follow a normal distribution. The ssGBLUP is a modified version of the traditional BLUP, in which the inverse of the pedigree-based relationship matrix $\left(A^{-\mathbf{1}}\right)$ is replaced by the $\boldsymbol{H}^{-\mathbf{1}}$ matrix. The $\boldsymbol{H}^{-\mathbf{1}}$ was defined as follows [42,43]:

$$
H^{-1}=A^{-1}+\left[\begin{array}{cc}
0 & 0 \\
0 & \tau G^{-1}-\omega A_{22}^{-1}
\end{array}\right]
$$

where $A^{-1}$ was previously defined, $\tau$ and $\boldsymbol{\omega}$ are the scaling factors used to combine the genomic relationship matrix $(G)$ and $A_{22}$, assumed as $\tau=1.0$ and $\boldsymbol{\omega}=0.7$ (defined based on preliminary analyses) in order to reduce the bias of the estimates [44], $\omega A_{22}^{-1}$ is the inverse of the pedigree-based relationship matrix $(A)$ for the genotyped animals, and $G^{-1}$ is the inverse of the $G$ matrix, which was calculated as [45]:

$$
G=Z^{\prime} / \mathbf{k}
$$

where $\mathbf{Z}$ is the matrix containing the centered genotypes accounting for the observed allelic frequencies and $\mathbf{k}$ is a scaling parameter, defined as $2 \sum \mathrm{p}(1-\mathrm{p})$, in which $\mathrm{p}$ is the observed allele frequency of each marker. The weighting factor can be derived either based on SNP frequencies [45], or by ensuring that the average diagonal of $G$ is close to that of $A_{22}$ [46]. In order to minimize issues with matrix inversion, 0.05 of $A$ was added to 0.95 of $G$.

\subsubsection{Genome-Wide Association Analysis}

GWAS was carried out for each trait based on the weighted ssGBLUP method (WssGBLUP) [29]. The same statistical models described to estimate the variance components and breeding values were used to identify the genomic windows associated with the traits, as described by Wang et al. [47], using the BLUPF90 program [40,41].

The POSTGSF90 program [38] was used to obtain SNP effects by back-solving the genomic estimated breeding values (GEBVs) for each trait. SNP effects and SNP weights were calculated following Wang et al. [47] based on three iterations. The GWAS results were reported as the proportion of the variance explained by a moving genomic window of 10 adjacent SNPs. Genomic windows that explained more than $1 \%$ of the total additive genetic variance were considered to be relevant, i.e., associated with AMH or AFP.

\subsubsection{Functional Analyses}

The candidate gene list from the genomic regions that explained at least $1 \%$ of genetic variance was annotated considering upstream and downstream intervals of $100 \mathrm{~kb}$ (threshold defined based on the level of linkage disequilibrium in the population) via the BioMart tool using the Ensembl Genes and the Bos taurus taurus ARS-UCD1.2 reference genome [48]. The DAVID v6.8 [49] software was used to perform the enrichment analysis according to the similarity of the biological processes and Kyoto Encyclopedia of Genes and Genomes (KEGG) pathways in which they are involved in $(p \leq$ 0.05; False Discover Rate $\leq 10)$, using all candidate genes identified for AMH and AFP. Furthermore, important SNPs (from the key genomic windows) were further explored using the Animal QTL Database (AnimalQTLdb) [50]. 


\section{Results}

\subsection{Variance Component and Genetic Parameter Estimates}

The descriptive statistics and genetic parameter estimates for AMH and AFP are presented in Table 1. The estimate of the genetic correlation between AMH and AFP was positive and of high magnitude $\left(r_{G}=0.81 \pm 0.02\right)$.

Table 1. Descriptive statistics, additive genetic variance $\left(\sigma^{2} a\right)$, residual variance $\left(\sigma^{2}{ }_{e}\right)$, heritability $\left(h^{2}\right)$, and standard error (SE) estimated for anti-Müllerian hormone (AMH) and antral follicle populations measure after estrous synchronization (AFP) in Nellore cattle.

\begin{tabular}{cccccc}
\hline Trait & Mean & $\mathrm{SD}^{3}$ & $\sigma^{2}{ }_{\boldsymbol{a}} \pm \mathrm{SE}$ & $\boldsymbol{\sigma}^{2}{ }_{\boldsymbol{e}} \pm \mathrm{SE}$ & $\boldsymbol{h}^{2} \pm \mathrm{SE}$ \\
\hline $\mathrm{AMH}^{1}$ & 1.10 & 0.36 & $0.16 \pm 0.10$ & $0.40 \pm 0.10$ & $0.28 \pm 0.07$ \\
$\mathrm{AFP}^{2}$ & 12.49 & 4.09 & $3.02 \pm 2.02$ & $7.13 \pm 1.96$ & $0.30 \pm 0.09$ \\
\hline
\end{tabular}

${ }^{1}$ Concentration in $\mathrm{ng} / \mathrm{mL}^{2}$ number of antral follicles $(\mathrm{n}){ }^{3}$ standard deviation.

\subsection{GWAS and Functional Analyses}

A total of 13 genomic regions located on BTA1, BTA3, BTA5, BTA7, BTA8, BTA10, BTA11, BTA18, BTA22, and BTA25 were identified for AMH (Table 2). Additionally, 18 genomic windows located on BTA1, BTA2, BTA4, BTA6, BTA8, BTA11, BTA14, BTA21, BTA26, BTA28, and BTA29 accounted for at least $1 \%$ of the total genetic variance for AFP (Table 3 ).

Table 2. Candidate genes located in the genomic windows that accounted for more than $1 \%$ of the total additive genetic variance for anti-Müllerian hormone levels in Nellore cattle.

\begin{tabular}{ccc}
\hline Chr:Position $\mathbf{( b p )} \mathbf{1}^{\mathbf{1}}$ & Candidate Genes & Var (\%) $^{\mathbf{2}}$ \\
\hline $5: 97,149,440-97,360,900$ & GPR19, CREBL2, DUSP16, BORCS5 & 5.22 \\
$7: 13,239,159-13,465,265$ & - & 3.20 \\
$1: 143,011,858-143,226,874$ & PDE9A, WDR4, NDUFV3, PKNOX1, CBS & 2.74 \\
$5: 23,779,410-24,021,506$ & $P L X N C 1$ & 2.00 \\
$3: 26,810,702-27,023,916$ & ATP1A1 & 1.84 \\
$1: 109,052,581-109,300,000$ & RSRC1 & 1.80 \\
$8: 75,771,507-75,987,944$ & FAM219A, DANI1, ENHO, CNTFR, RPP25L, DCTN3 & 1.75 \\
$22: 26,343,690-26,562,220$ & - & 1.54 \\
$25: 21,973,041-22,186,659$ & CACNG3 & 1.49 \\
$1: 64,865,063-65,123,147$ & GPR156, LRRC58 & 1.43 \\
$10: 10,957,392-11,173,990$ & MTX3, THBS4, SERINC5 & 1.30 \\
$18: 7,065,051-7,298,879$ & - & 1.25 \\
$11: 6,614,691-6,831,396$ & MAP4K4, IL1R2 & 1.15 \\
\hline
\end{tabular}

${ }^{1}$ Chromosome; ${ }^{2}$ Var $(\%)=$ proportion of the total additive genetic variance. 
Table 3. Candidate genes located in the genomic windows that accounted for more than $1 \%$ of the total additive genetic variance for antral follicle populations in Nellore cattle.

\begin{tabular}{|c|c|c|}
\hline Chr:Position (bp) ${ }^{1}$ & Candidate Genes & $\operatorname{Var}(\%)^{2}$ \\
\hline $26: 45,605,887-45,832,830$ & ADAM12 & 7.33 \\
\hline $1: 109,036,868-109,295,720$ & RSRC1 & 6.24 \\
\hline $14: 68,529,242-68,764,179$ & - & 3.37 \\
\hline $1: 64,905,320-65,192,584$ & GPR156, LRRC58, FSTL1 & 3.19 \\
\hline $14: 4,866,037-5,110,734$ & - & 3.07 \\
\hline $6: 13,887,045-14,107,585$ & - & 3.05 \\
\hline $8: 86,936,023-87,174,520$ & SYK & 2.93 \\
\hline $2: 16,843,125-17,099,561$ & ZNF385B & 1.98 \\
\hline $2: 16,761,007-16,999,128$ & CWC22 & 1.79 \\
\hline $26: 39,682,007-39,898,965$ & TIAL1, BAG3, INPP5F & 1.70 \\
\hline $28: 478,980-713,335$ & RHOU & 1.60 \\
\hline $4: 77,214,698-77,441,075$ & POLM, BLVRA, COA1 & 1.53 \\
\hline $6: 13,909,732-14,132,804$ & - & 1.49 \\
\hline $11: 48,459,747-48,702,594$ & REEP1, MRPL35, IMMT & 1.28 \\
\hline $1: 157,802,376-158,023,994$ & GPX5 & 1.07 \\
\hline $29: 23,486,872-23,711,141$ & - & 1.04 \\
\hline $21: 62,231,714-62,455,313$ & - & 1.03 \\
\hline $4: 10,571,640-10,785,338$ & HEPACAM2, VPS50, CALCR & 1.00 \\
\hline
\end{tabular}

${ }^{1}$ Chromosome; ${ }^{2} \operatorname{Var}(\%)=$ proportion of the total additive genetic variance.

The chromosomes BTA5 and BTA7 demonstrated the most important genomic regions associated with AMH. For AFP, the two highest peaks were identified on BTA1 (at 109.1 Mb) and BTA26 (at $45.7 \mathrm{Mb}$ ), which accounted for $6.24 \%$ and $7.33 \%$ of the total additive genetic variance, respectively. The highest peak for AMH was found on BTA5 (at $97.2 \mathrm{Mb}$ ) explaining $5.22 \%$ of the total additive genetic variance. Two overlapping regions located on BTA1 (64.9-65.0 Mb and 109.1-109.2 Mb) were found for the two traits, as illustrated in Figures 1 and 2.

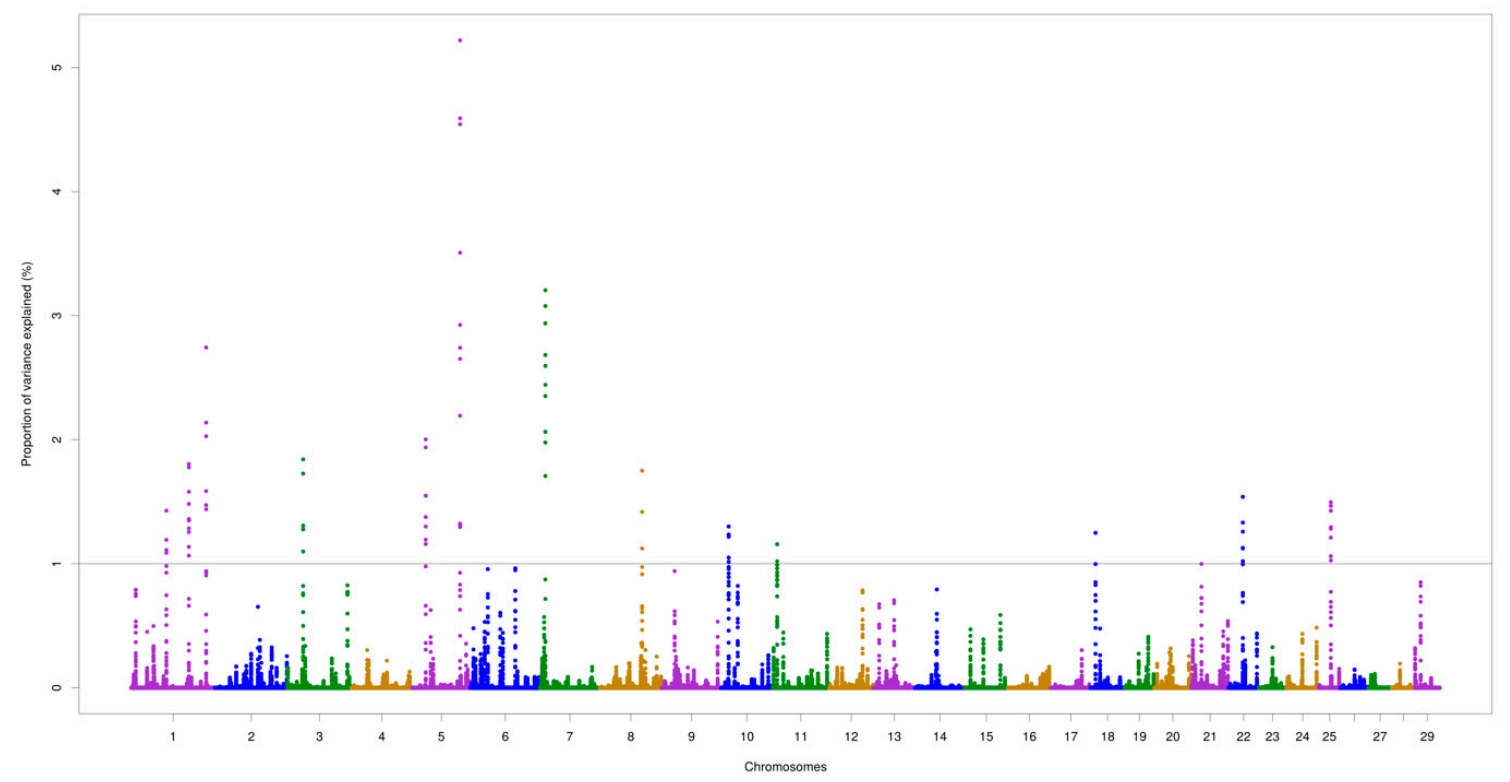

Figure 1. Genomic regions for anti-Mullerian hormone (AMH) levels in Nellore cattle. The grey line represents the threshold $(1 \%)$ of the proportion of total additive genetic variance accounted for by each genomic window. 


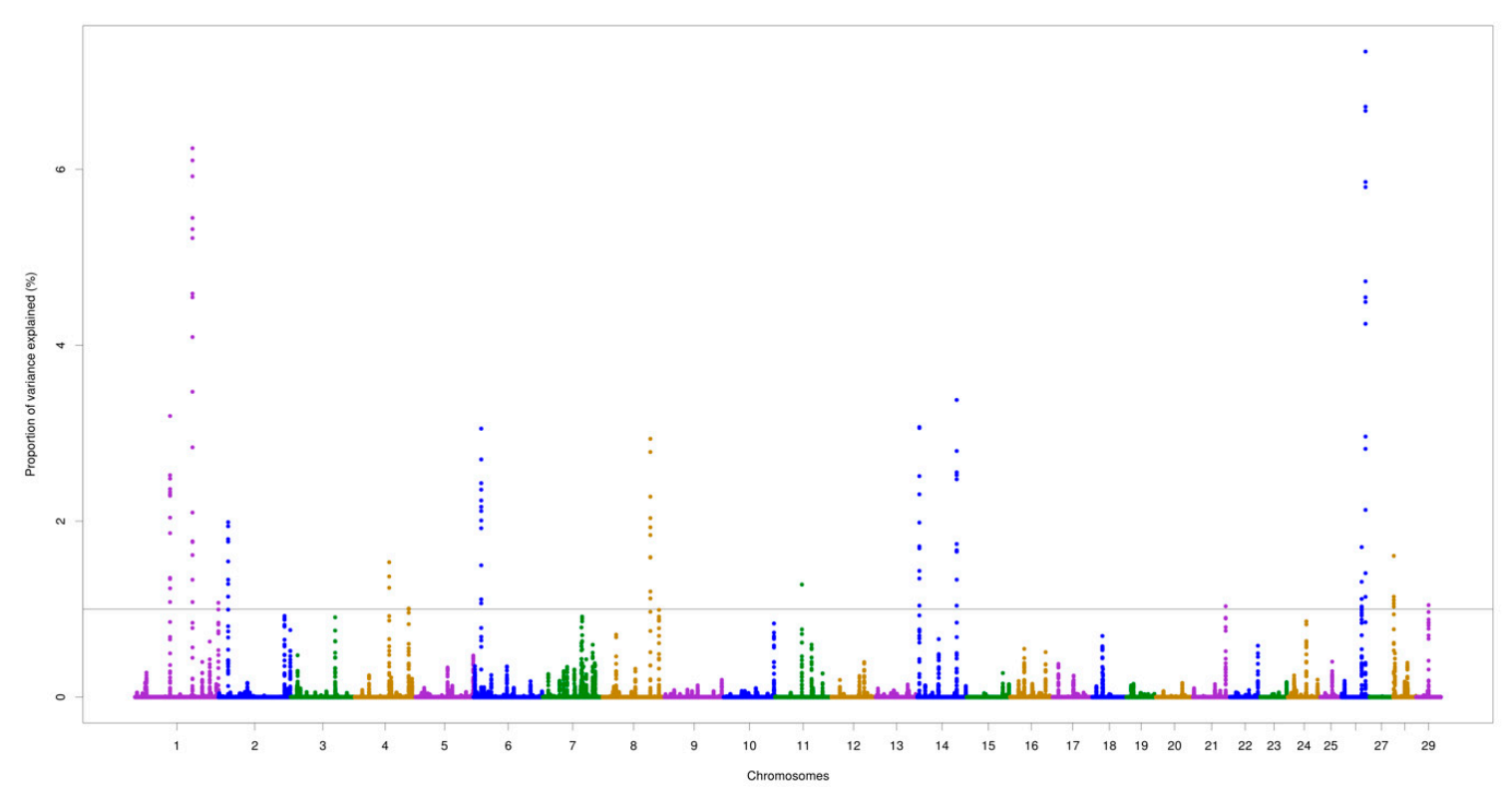

Figure 2. Genomic regions for antral follicle populations (AFP) in Nellore cattle. The grey line represents the threshold (1\%) of the proportion of total additive genetic variance accounted for by each genomic window.

Totals of 26 and 22 positional candidate genes were identified for AMH and AFP, respectively. For AMH, one (PLXNC1) and four (GRP19, CREBL2, DUSP16, and BORCS5) positional genes were detected on BTA5, located around $24.0 \mathrm{Mb}$ and between 97.1 and $97.4 \mathrm{Mb}$, respectively. A group of genes (ADAM12, TIAL1, BAG3, and INPP5F) were found to be harbored within the genomic region located on BTA26 for AFP. The overlapping regions described above shared three candidate genes, namely, RSRC1, GPR156, and LRRC58. Five biological processes and one pathway were enriched $(p \leq 0.05)$, including pathways associated with the ovulation process (Table 4$)$.

Table 4. Most significant $(p \leq 0.05)$ biological processes (BP) and KEGG pathways for anti-Müllerian hormone levels and antral follicle populations in Nellore cattle.

\begin{tabular}{|c|c|c|c|c|}
\hline Type $^{1}$ & Term & Candidate Genes & $p$-Value & FDR \\
\hline $\mathrm{BP}$ & GO:0048771 tissue remodeling & THBS4, CBS, SYK & 0.024 & 3.2 \\
\hline $\mathrm{BP}$ & GO:0051301 cell division & $\begin{array}{l}\text { TIAL1, HEPACAM2, } \\
\text { DCTN3, THBS4 }\end{array}$ & 0.036 & 4.4 \\
\hline $\mathrm{BP}$ & $\begin{array}{c}\text { GO:0007005 mitochondrion } \\
\text { organization }\end{array}$ & $\begin{array}{l}\text { MTX3, IMMT, COA1, } \\
\text { RHOU, MRPL35 }\end{array}$ & 0.040 & 4.8 \\
\hline $\mathrm{BP}$ & $\begin{array}{c}\text { GO:0009605 response to external } \\
\text { stimulus }\end{array}$ & $\begin{array}{c}\text { IL1R2, SERINC5, } \\
\text { PLXNC1, BAG3, FSTL1, } \\
\text { THBS4, CBS, SYK }\end{array}$ & 0.045 & 5.2 \\
\hline $\mathrm{BP}$ & $\begin{array}{c}\text { GO:0051049 regulation of } \\
\text { transport }\end{array}$ & $\begin{array}{c}\text { IL1R2, ATP1A1, } \\
\text { CACNG3, REEP1, RHOU, } \\
\text { CREBL2, SYK }\end{array}$ & 0.048 & 5.4 \\
\hline KEGG & $\begin{array}{c}\text { bta04010:MAPK signaling } \\
\text { pathway }\end{array}$ & $\begin{array}{l}\text { MAP4K4, DUSP16, } \\
\text { CACNG3 }\end{array}$ & 0.049 & 3.8 \\
\hline
\end{tabular}

${ }^{1}$ BP: Biological process; KEGG: Kyoto Encyclopedia of Genes and Genomes (KEGG) pathway; FDR: False Discovery Rate based on the Benjamini-Hochberg (BH) method [51].

\section{Discussion}

The circulating concentrations of AMH are highly variable among mammalian species. In the current study, the AMH mean agreed with Zebu cattle reports, which ranged from 1.20 to 1.60 $\mathrm{ng} / \mathrm{mL}[21,24,48]$. These values were higher when compared with those reported for Taurine breeds $(0.78 \mathrm{ng} / \mathrm{mL}$ [52]). In this study, high AMH plasma concentration was associated with greater AFP (>25). 
In this context, Morotti et al. [52] reported a strong $\left(r_{G}=0.88\right)$ genetic correlation between AMH and AFP, which was in agreement with our current findings, highlighting the importance of measuring $\mathrm{AMH}$ concentration to identify precocious cows through follicular and ovulatory responses [53]. AFP was quantified after an estrous synchronization protocol, thereby indicating the response to a drug-induced treatment. This was done because estrous synchronization is a common practice in the cattle industry and also facilitates the measurement of individual animals at the same stage of reproduction, thus reducing environmental influence that could be difficult to account for in the statistical models.

Recently, Nawaz et al. [34] obtained higher heritability estimates for AMH based on pedigree $(0.43 \pm 0.07)$ or genomic $(0.36 \pm 0.03)$ information in Holstein cattle compared to the estimates found in the present study. Gobikrushanth et al. [20] also reported a high $(0.46 \pm 0.31)$ heritability estimate for $\mathrm{AMH}$ in Holstein cows. The high standard error in the last study might be due to the low $(\mathrm{n}=$ 198) number of cows with phenotypic records, data structures, and transformation of phenotypic data. The AMH heritability estimate observed in Nellore heifers $\left(h^{2}=0.28 \pm 0.07\right)$ was lower when compared to the literature reports, however, a lower standard error was also observed in the current study. This moderate heritability indicated that substantial genetic progress could be achieved through direct genetic selection.

Júnior et al. [54] reported higher heritability estimates for AFP $(0.49 \pm 0.09)$ in Nellore cattle compared to our findings. Moderate to high positive genetic correlations between AMH and AFP were reported to range from 0.56 to 0.68 in Nellore cattle and 0.73 to 0.90 in Holstein animals [52,55]. Since $\mathrm{AMH}$ is already certified as an endocrine marker of ovarian reserve in women [56], this significant positive correlation indicated that both traits could be incorporated into Nellore cattle breeding programs. Some authors [12,23,53] indicated a practical advantage in the use of AMH instead of predicting AFP using an ultrasound approach. The levels of circulating AMH are stable during the estrous cycle [53], therefore, it can be measured at any time during that period. AMH is expected to be a useful trait to identify animals that are better oocyte donors in superovulation protocols. Nawaz et al. [34] reported significant genomic regions on BTA11 (92.8 to $97.1 \mathrm{Mb}$ ) and BTA20 (25.0 to 26.3 Mb). In this present study, genomic regions on BTA11 (around $6 \mathrm{Mb}$ ) for AMH and BTA11 (around $48 \mathrm{Mb}$ ) for AFP were observed. Moreover, these authors [34] reported gene members of the TGF- $\beta$ family involved in follicular development, cell proliferation, steroidogenesis, and ovulation.

Similar to our findings, three genomic windows located in BTA8 (4.16-7.66 Mb), BTA11 (69.4-73.6 Mb), and BTA22 (11.9-15.9 Mb) were associated with AFP in Nellore heifers [54]. These regions harbor important candidate genes ( $A D A M 29, C T S B, S O X 7, P P P 1 C B, C L I P 4$, and CCK) associated with fertility traits. The significant peak on BTA26 around $46 \mathrm{Mb}$ harbors the gene ADAM12 (Adam metallopeptidase domain 12), which is associated with several biological activities, such as regulating remodeling of extracellular matrix, modulation of cell morphological changes, satellite cell activation, regulation of myogenesis and adipogenesis in beef cattle [57], and regulation of TGF- $\beta 1$ [58], a gene involved in follicular development, cell proliferation, steroidogenesis, and ovulation [59]. Evidence exists regarding the function of the metalloprotease domain (ADAM) gene family in the ovarian follicle, follicular development, and ovarian organization [60,61]. The three proteases (ADAM9, ADAM10, and $A D A M 12)$ together seem to regulate the breakdown of matrix and differentiation of granulosa cells prior to ovulation [62]. The BAG3 (BTA26:39.7-39.8 Mb) and TIAL1 (BTA26:39.6-39.7 Mb) genes were also annotated. TIAL1 acts on post-transcriptional regulation encoding protein members of the RNA binding family, and has also been associated to the development of primordial germ cells of gametes (i.e., sperm and oocytes) in rodents [63]. In addition, BAG3 was annotated in proximity to a QTL affecting daughter pregnancy rate in Nellore beef cattle [3].

The enrichment analysis (Table 4) highlighted five biological processes and one KEGG pathway related to AMH and AFP. The response to an external stimulus term comprises any mechanism that regulates or modifies the gene expression or secretion or enzyme production as a result of an external stimulus (e.g., nutritional, environmental, maternal behavior) or epigenomics [64]. In livestock, various studies investigated the molecular epigenetic mechanisms that regulate the expression of certain 
genes potentially involved in reproductive traits' expression, sometimes as a response to an external stimulus [65-68]. It is important to highlight that multiple external factors can leave epigenetic marks that could affect further generations and may be related to the activity and levels of AMH and AFP. The group of genes involved in this biological process (response to external stimulus; IL1R2, SERINC5, PLXNC1, THBS4, and CBS) are implicated in the ovulation process, tissue remodeling, immune system, and embryo preimplantation [69,70]. PLXNC1 (Plexin C1) is associated with the immune system [50] and belongs to a subfamily of plexin genes which function as receptors for semaphorins to influence neuronal development and function. The immune system regulates physiological interactions to support internal protection, health, and survival of the embryo. Herein, the interaction between the immune and reproductive systems are of particular interest [71]. The main interaction between the systems is related to endocrine and immune response during gestation [72]. Particularly, IL1R2 is a glycoprotein expressed on monocytes, neutrophils, and T and B lymphocytes. Part of the interleukin family, the type 2 form of $I L-1$, was extensively related to ovulation during follicular growth [69]. THBS4 is a calcium-binding protein that modulates cellular phenotype during tissue genesis and remodeling [73]. In this regard, ovulation was suggested to be a tissue remodeling process, annotated as a significant biological process term $(p=0.02)$. The genes CNTFR and ATP1A1 are associated with productive efficiency (e.g., average daily gain, feed efficiency) [74] and heat tolerance [75-77] indicators. Selection for fertility along with production traits is, therefore, readily justifiable. ATP1A1 was reported to be related to heat tolerance [71], in which heat stress response can affect cattle reproductive performance [76,77]. ATP1A1 may also influence mastitis resistance [78].

The KEGG protein processing in the Mitogen-Activated Protein Kinase (MAPK) signaling pathway is involved in a conserved module that controls various cellular events and biological processes, such as embryogenesis, cell differentiation, cell proliferation, cell death, short-term changes required for homeostasis, and acute hormonal responses [79-81]. Also, this pathway is associated with preimplantation embryogenesis [82], defined as the time interval from conception to nidation or attachment of the embryo to the uterus, a crucial stage in successful pregnancies related to embryonic health, and therefore reproductive efficiency [83].

There are known QTLs located in the genomic regions identified in this study, including associations with calving performance (e.g., calving ease, calf size) [84]. In agreement with our findings, previous studies in Angus and Hereford cattle detected the MAPK signaling pathway as having a pleiotropic effect on birth weight, calving ease (direct and maternal), and calving performance traits [85-88]. Likewise, QTLs linked to gestation length, the interval to first estrus after calving [89], conception rate [90], and heifer pregnancy [91] overlapped with various genomic regions identified for AMH and AFP. The anti-Mullerian hormone receptor type 2 (AMHR2) gene was not identified as significant in this study, but was reported as an important gene related to $\mathrm{AMH}[9,92,93]$. Surprisingly, a genomic window harboring the AMHR2 gene, located at BTA5:26,591,483-26,597,710, only explained 0.001\% of the total additive genetic variance for AMH. However, a genomic region identified on BTA5 may capture the effect of this gene through linkage disequilibrium (Figure 1), or prove that the polymorphisms in other genes involved in the AMH metabolic process are of greater importance. In this context, Pierucci et al. [94] investigated the association between polymorphisms in the $A M H$ gene and early pregnancy occurrence and age at first calving in Nellore cattle, but also did not find significant additive effects of the three SNPs investigated.

Despite the fact that AMH and AFP are highly genetic correlated traits $(0.81 \pm 0.02)$, a limited number of overlapping genomic regions were identified, indicating that the genes with pleiotropic effects for AMH and AFP might be genes with small effects. Furthermore, based on the heritability estimates and large number of genomic regions with small effects, AMH and AFP seem to be traits of complex inheritance regulated by a large number of small-effect genes.

Genetic selection for AMH and AFP in Nellore cattle is expected to improve reproductive performance, especially superovulatory responses. Furthermore, breeding values for these traits can be used to select the best oocyte donors for in vitro embryo production. The number of genotyped animals 
with phenotypes for $\mathrm{AMH}$ is a limiting factor that needs to be increased in future studies, as this impacts the identification of important genomic regions with smaller effects. However, the use of a high-density SNP panel may have minimized this issue, as the average linkage disequilibrium between markers was greater compared to a lower density SNP panel. Further studies using datasets from independent populations, as well as larger datasets in this current population, should be performed to validate the findings of this study. AFP can be measured at a reasonably low cost per individual and, as $\mathrm{AMH}$ and AFP are highly and positively genetic correlated, AFP could be a feasible indicator for inclusion in breeding schemes.

\section{Conclusions}

Our findings indicated that anti-Müllerian hormone levels and antral follicle populations (measured after a synchronization protocol) are heritable traits in Nellore cattle and can be improved through genetic and genomic selection. Furthermore, breeding values for both traits can be used to identify females that best respond to superovulation that are better oocyte donors for in vitro embryo production. Substantial indirect genetic gains are expected by selecting for only one of the two traits, as a high positive correlation was observed between them. A total of 31 genomic regions were identified to be associated with AMH or AFP, and two genomic regions located on BTA1 overlapped between the traits. Various candidate genes were identified to be potentially linked to important biological processes such as ovulation, tissue remodeling, and the immune system. Anti-Müllerian hormone levels and antral follicle populations could be used as indicator traits to genetically improve fertility rates in Nellore cattle and to identify better oocyte donors. Future studies should also investigate the genomic backgrounds of these traits in the absence of an estrous synchronization protocol.

Author Contributions: Conceptualization, L.G., J.B.S.F., P.S.B., and H.N.K.; methodology, L.G., J.B.S.F., and L.F.B.; formal analysis, L.G. and L.F.B.; investigation, L.G., J.B.S.F., and L.F.B.; resources, J.B.S.F., P.S.B., H.N.K., and M.F.G.N.; data curation, L.G., J.P.E., J.B.S.F., and P.S.B.; writing-original draft preparation, L.G. and L.F.B.; writing-review and editing, M.H.A.S., F.F.B., and L.F.B.; visualization, L.G.; supervision, J.B.S.F. and L.F.B.; project administration, L.G., J.B.S.F., and L.F.B.; funding acquisition, J.B.S.F., P.S.B., and M.F.G.N. All authors reviewed and approved the final version of the manuscript.

Funding: This research was funded by The Sao Paulo Research Foundation (FAPESP—grant numbers: 2012/50533-2, 2014/07566-2, and 2017/11919-6).

Acknowledgments: The authors acknowledge all researchers involved in The Genomic Improvement of Fertilization Traits in Danish and Brazilian Cattle and FAPESP.

Conflicts of Interest: The authors declare no conflict of interest.

\section{References}

1. Summers, A.F.; Rosasco, S.L.; Scholljegerdes, E.J. Beef species-ruminant nutrition cactus beef symposium: Influence of management decisions during heifer development on enhancing reproductive success and cow longevity. J. Anim. Sci. 2019, 97, 1407-1414. [CrossRef] [PubMed]

2. Ramos, P.V.B.; e Silva, F.F.; da Silva, L.O.C.; Santiago, G.G.; de Menezes, G.R.O.; Soriano Viana, J.M.; Torres Júnior, R.A.A.; Gondo, A.; Brito, L.F. Genomic evaluation for novel stayability traits in Nellore cattle. Reprod. Domest. Anim. 2020, 55, 266-273. [CrossRef]

3. Nascimento, A.V.D.; Da Silva Romero, Â.R.; Utsunomiya, Y.T.; Utsunomiya, A.T.H.; Cardoso, D.F.; Neves, H.H.R.; Carvalheiro, R.; Garcia, J.F.; Grisolia, A.B. Genome-wide association study using haplotype alleles for the evaluation of reproductive traits in Nelore cattle. PLoS ONE 2018, 13, e0201876. [CrossRef]

4. $\quad$ Buzanskas, M.E.; Pires, P.S.; Chud, T.C.S.; Bernardes, P.A.; Rola, L.D.; Savegnago, R.P.; Lôbo, R.B.; Munari, D.P. Parameter estimates for reproductive and carcass traits in Nelore beef cattle. Theriogenology 2017, 92, $204-209$. [CrossRef] [PubMed]

5. Cammack, K.M.; Thomas, M.G.; Enns, R.M. Reproductive Traits and Their Heritabilities in Beef Cattle. Prof. Anim. Sci. 2009, 25, 517-528. [CrossRef]

6. Terakado, A.P.N.; Boligon, A.A.; Baldi, F.; Silva, J.I.V.; Albuquerque, L.G. Genetic associations between scrotal circumference and female reproductive traits in Nelore cattle. J. Anim. Sci. 2015, 93, 2706-2713. [CrossRef] 
7. Costa, E.V.; Ventura, H.T.; Veroneze, R.; Silva, F.F.; Pereira, M.A.; Lopes, P.S. Estimated genetic associations among reproductive traits in Nellore cattle using Bayesian analysis. Anim. Reprod. Sci. 2020, $214,106305$. [CrossRef]

8. Barbosa, A.C.B.; Carneiro, P.L.S.; Rezende, M.P.G.; Ramos, I.O.; Martins Filho, R.; Malhado, C.H.M. Parâmetros genéticos para características de crescimento e reprodutivas em bovinos. Arch. Zootec. 2017, 66, 449-452. [CrossRef]

9. Poole, D.H.; Ocón-grove, O.M.; Johnson, A.L. Theriogenology Anti-Müllerian hormone (AMH) receptor type II expression and AMH activity in bovine granulosa cells. Theriogenology 2016, 86, 1353-1360. [CrossRef]

10. Guerreiro, B.M.; Batista, E.O.S.; Vieira, L.M.; Filho, M.F.S.; Rodrigues, C.A.; Netto, A.C.; Silveira, C.R.A.; Bayeux, B.M.; Dias, E.A.R.; Monteiro, F.M.; et al. Domestic Animal Endocrinology Plasma anti-mullerian hormone: An endocrine marker for in vitro embryo production from Bos taurus and Bos indicus donors. Domest. Anim. Endocrinol. 2014, 49, 96-104. [CrossRef]

11. Brodin, T.; Hadziosmanovic, N.; Berglund, L.; Olovsson, M.; Holte, J. Antimüllerian hormone levels are strongly associated with live-birth rates after assisted reproduction. J. Clin. Endocrinol. Metab. 2013, 98, 1107-1114. [CrossRef] [PubMed]

12. Baruselli, P.S.; Batista, E.O.S.; Vieira, L.M.; Souza, A.H. Relationship between follicle population, AMH concentration and fertility in cattle Bubalus Murrah bubalis Gyr indicus Bos. Anim. Reprod. 2015, 12, 487-497.

13. Pontes, J.H.F.; Melo Sterza, F.A.; Basso, A.C.; Ferreira, C.R.; Sanches, B.V.; Rubin, K.C.P.; Seneda, M.M. Ovum pick up, in vitro embryo production, and pregnancy rates from a large-scale commercial program using Nelore cattle (Bos indicus) donors. Theriogenology 2011, 75, 1640-1646. [CrossRef] [PubMed]

14. Vieira, R.J. Biotécnicas Aplicadas À Reprodução Bovina: Generalidades. Ciência Anim. Edição Espec Ciência Anim. 2012, 22, 55-65.

15. Jaguszeski, M.Z.; Neto, A.P.; De Oliveira, W.; Cattelam, J.; Gregianini, H.A.G. Pregnancy rate of recipient cows after transfer of in vitro-produced nellore embryos. Rev. Caatinga 2019, 32, 1087-1091. [CrossRef]

16. Baruselli, P.S.; Batista, E.O.S.; Vieira, L.M.; de Sales, J.N.S.; Gimenes, L.U.; Ferreira, R.M. Intrinsic and extrinsic factors that influence ovarian environment and efficiency of reproduction in cattle. Anim. Reprod. 2017, 14, 48-60. [CrossRef]

17. Mossa, F.; Jimenez-Krassel, F.; Scheetz, D.; Weber-Nielsen, M.; Evans, A.C.O.; Ireland, J.J. Anti-Müllerian Hormone (AMH) and fertility management in agricultural species. Reproduction 2017, 154, R1-R11. [CrossRef]

18. Mossa, F.; Ireland, J.J. Physiology and endocrinology symposium: Anti-Müllerian hormone: A biomarker for the ovarian reserve, ovarian function, and fertility in dairy cows. J. Anim. Sci. 2019, 97, 1446-1455. [CrossRef]

19. Cardoso, C.J.T.; de Junior, J.S.O.; Kischel, H.; da Silva, W.A.L.; da Arruda, E.D.S.; Souza-Cáceres, M.B.; de Oliveira, F.A.M.; Nogueira, É.; de Nogueira, G.P.; de Melo-Sterza, F.A. Anti-Müllerian hormone (AMH) as a predictor of antral follicle population in heifers. Anim. Reprod. 2018, 15, 12-16. [CrossRef]

20. Gobikrushanth, M.; Purfield, D.C.; Colazo, M.G.; Butler, S.T.; Wang, Z.; Ambrose, D.J. The relationship between serum anti-Müllerian hormone concentrations and fertility, and genome-wide associations for anti-Müllerian hormone in Holstein cows. J. Dairy Sci. 2018, 1-12. [CrossRef]

21. Batista, E.O.S.; Vieira, L.M.; Freitas, B.G.; Guerreiro, B.M.; Soares, J.G.; Mingoti, R.D.; Vasconcellos, G.; Souza, A.H.; Ferraz, J.B.S.; Baruselli, P.S. Anti-Mullerian Hormone and its relationship to ovulation response and fertility in timed AI Bos indicus heifers. Reprod. Domest. Anim. 2020. [CrossRef] [PubMed]

22. Maculan, R.; Pinto, T.L.C.; Moreira, G.M.; de Vasconcelos, G.L.; Sanches, J.A.; Rosa, R.G.; Bonfim, R.R.; de Gonçalves, T.M.; de Souza, J.C. Anti-Müllerian Hormone (AMH), antral follicle count (AFC), external morphometrics and fertility in Tabapuã cows. Anim. Reprod. Sci. 2017. [CrossRef] [PubMed]

23. Souza, A.H.; Carvalho, P.D.; Rozner, A.E.; Vieira, L.M.; Hackbart, K.S.; Bender, R.W.; Dresch, A.R. Relationship between circulating anti-Müllerian hormone (AMH) and superovulatory response of high-producing dairy cows. J. Dairy Sci. 2015, 98, 169-178. [CrossRef]

24. Gamarra, G.; Ponsart, C.; Lacaze, S.; Le Guienne, B.; Humblot, P.; Deloche, M.C.; Monniaux, D.; Ponter, A.A. Dietary propylene glycol and in vitro embryo production after ovum pick-up in heifers with different anti-Müllerian hormone profiles. Reprod. Fertil. Dev. 2015, 27, 1249-1261. [CrossRef] [PubMed]

25. Vernunft, A.; Schwerhoff, M.; Viergutz, T.; Diederich, M.; Kuwer, A. Anti-Muellerian hormone levels in plasma of Holstein-Friesian heifers as a predictive parameter for ovum pick-up and embryo production outcomes. J. Reprod. Dev. 2015, 61, 1-6. [CrossRef] [PubMed] 
26. Ribeiro, E.S. Plasma anti-Mullerian hormone in adult dairy cows and associations with fertility. J. Dairy Sci. 2014, 97, 6888-6900. [CrossRef]

27. Scheetz, D.; Pursley, J.R. Concentration of anti-Müllerian hormone in dairy heifers is positively associated with productive herd life. J. Dairy Sci. 2015. [CrossRef]

28. Zhang, H.; Wang, Z.; Wang, S.; Li, H. Progress of genome wide association study in domestic animals. J. Anim. Sci. Biotechnol. 2012, 3, 26. [CrossRef]

29. Naha, B.C.; Prasad, A.; Sailo, L.; Chaudhary, R.; Prakash, O. Concept of genome wide association studies and its progress in livestock. Int. J. Sci. Nat. 2016, 7, 39-42.

30. Grigoletto, L.; Brito, L.F.; Mattos, E.C.; Eler, J.P.; Bussiman, F.O.; da Silva, B.C.A.; da Silva, R.P.; Carvalho, F.E.; Berton, M.P.; Baldi, F.; et al. Genome-wide associations and detection of candidate genes for direct and maternal genetic effects influencing growth traits in the Montana Tropical ${ }^{\circledR}$ Composite population. Livest. Sci. 2019, 229, 64-76. [CrossRef]

31. Grigoletto, L.; Ferraz, J.B.S.; Oliveira, H.R.; Eler, J.P.; Bussiman, F.O.; Abreu Silva, B.C.; Baldi, F.; Brito, L.F. Genetic Architecture of Carcass and Meat Quality Traits in Montana Tropical ${ }^{\circledR}$ Composite Beef Cattle. Front. Genet. 2020, 11, 1-13. [CrossRef] [PubMed]

32. Guarini, A.R.; Lourenco, D.A.L.; Brito, L.F.; Sargolzaei, M.; Baes, C.F.; Miglior, F.; Misztal, I.; Schenkel, F.S. Genetics and genomics of reproductive disorders in Canadian Holstein cattle. J. Dairy Sci. 2019, 102, 1341-1353. [CrossRef] [PubMed]

33. Fleming, A.; Baes, C.F.; Martin, A.A.A.; Chud, T.C.S.; Malchiodi, F.; Brito, L.F.; Miglior, F. Symposium review: The choice and collection of new relevant phenotypes for fertility selection. J. Dairy Sci. 2019, 102, 3722-3734. [CrossRef]

34. Nawaz, M.Y.; Jimenez-Krassel, F.; Steibel, J.P.; Lu, Y.; Baktula, A.; Vukasinovic, N.; Neuder, L.; Ireland, J.L.H.; Ireland, J.J.; Tempelman, R.J. Genomic heritability and genome-wide association analysis of anti-Müllerian hormone in Holstein dairy heifers. J. Dairy Sci. 2018, 101, 1-13. [CrossRef] [PubMed]

35. Batista, E.O.S.; Macedo, G.G.; Sala, R.V.; Ortolan, M.; Mf, S. Plasma Antimullerian Hormone as a Predictor of Ovarian Antral Follicular Population in Bos indicus (Nelore) and Bos taurus (Holstein) Heifers. Reprod. Domest. Anim. 2014, 452, 448-452. [CrossRef] [PubMed]

36. Freitas, B.G. Influência do Desenvolvimento Corporal na Resposta aos Programas de Sincronização Para Inseminação Artificial em Tempo Fixo em Novilhas Nelore de 14 Meses de Idade. Ph.D. Thesis, Faculdade de Medicina Veterinária e Zootencia, Universidade de São Paulo, São Paulo, Brazil, 2015.

37. Yang, H.; Su, G. Impact of phenotypic information of previous generations and depth of pedigree on estimates of genetic parameters and breeding values. Livest. Sci. 2016, 187, 61-67. [CrossRef]

38. Aguilar, I.; Misztal, I.; Tsuruta, S. PREGSF90-POSTGSF90: Computational tools for the implementation of single-step genomic selection and genome-wide association with ungenotyped. In Proceedings of the 10th World Congress on Genetics Applied to Livestock Production, Vancouver, BC, Canada, 17-22 August 2014; pp. 90-92. [CrossRef]

39. Wiggans, G.R.; Sonstegard, T.S.; VanRaden, P.M.; Matukumalli, L.K.; Schnabel, R.D.; Taylor, J.F.; Schenkel, F.S.; Van Tassell, C.P. Selection of single-nucleotide polymorphisms and quality of genotypes used in genomic evaluation of dairy cattle in the United States and Canada. J. Dairy Sci. 2009, 92, 3431-3436. [CrossRef]

40. Misztal, I. BLUPF90-A Flexible Mixed Model Program in Fortran 90; University of Georgia: Athens, GA, USA, 2012.

41. Misztal, I.; Tsuruta, S.; Strabel, T.; Auvray, B.; Druet, T.; Lee, D.H. Blupf90 and Related Programs (Bgf90). In Proceedings of the 7th World Congress on Genetics Applied to Livestock Production, Montpellier, France, 19-23 August 2002; pp. 2001-2002.

42. Legarra, A.; Aguilar, I.; Misztal, I. A relationship matrix including full pedigree and genomic information. J. Dairy Sci. 2009, 92, 4656-4663. [CrossRef]

43. Aguilar, I.; Misztal, I.; Johnson, D.L.; Legarra, A.; Tsuruta, S.; Lawlor, T.J. Hot topic: A unified approach to utilize phenotypic, full pedigree, and genomic information for genetic evaluation of Holstein final score. J. Dairy Sci. 2010, 93, 743-752. [CrossRef]

44. Tsuruta, S.; Misztal, I.; Aguilar, I.; Lawlor, T.J. Multiple-trait genomic evaluation of linear type traits using genomic and phenotypic data in US Holsteins. J. Dairy Sci. 2011, 94, 4198-4204. [CrossRef]

45. VanRaden, P.M. Efficient Methods to Compute Genomic Predictions. J. Dairy Sci. 2008, 91, 4414-4423. [CrossRef] 
46. Vitezica, Z.G.; Aguilar, I.; Misztal, I.; Legarra, A. Bias in genomic predictions for populations under selection. Genet. Res. 2011, 93, 357-366. [CrossRef] [PubMed]

47. Wang, H.; Misztal, I.; Aguilar, I.; Legarra, A.; Fernando, R.L.; Vitezica, Z.; Okimoto, R.; Wing, T.; Hawken, R.; Muir, W.M. Genome-wide association mapping including phenotypes from relatives without genotypes in a single-step (ssGWAS) for 6-week body weight in broiler chickens. Front. Genet. 2014, 5, 1-10. [CrossRef]

48. Zerbino, D.R.; Achuthan, P.; Akanni, W.; Amode, M.R.; Barrell, D.; Bhai, J.; Billis, K.; Cummins, C.; Gall, A.; Girón, C.G.; et al. Ensembl 2018. Nucleic Acids Res. 2018, 46, D754-D761. [CrossRef]

49. Huang, D.W.; Sherman, B.T.; Tan, Q.; Collins, J.R.; Alvord, G.; Roayaei, J.; Stephens, R.; Baseler, M.W.; Lane, C.; Lempicki, R.A. The DAVID Gene Functional Classification Tool: A novel biological module-centric algorithm to functionally analyze large gene lists. Genome Biol. 2007, 8. [CrossRef] [PubMed]

50. Hu, Z.L.; Park, C.A.; Reecy, J.M. Building a livestock genetic and genomic information knowledgebase through integrative developments of Animal QTLdb and CorrDB. Nucleic Acids Res. 2019, 47, D701-D710. [CrossRef] [PubMed]

51. Ge, W.; Fazal, Z.; Jakobsson, E. Using Optimal and Random Resampling in Gene Ontology Enrichment Calcula-. Front. Appl. Math. Stat. 2019, 5, 20. [CrossRef]

52. Morotti, F.; Barreiros, T.R.R.; Machado, F.Z.; González, S.M.; Marinho, L.S.R.; Seneda, M.M. Is the number of antral follicles an interesting selection criterium for fertility in cattle? Anim. Reprod. 2015, 12, 479-486.

53. Rico, C.; Fabre, S.; Medigue, C.; Clemente, N.D.; Clement, F.; Bontoux, M.; Touze, J.-L.; Dupont, M.; Briant, E.; Remy, B.; et al. Anti-Mullerian Hormone Is an Endocrine Marker of Ovarian Gonadotropin-Responsive Follicles and Can Help to Predict Superovulatory Responses in the Cow 1. Biol. Reprod. 2009, 80, 50-59. [CrossRef] [PubMed]

54. Júnior, G.A.O.; Perez, B.C.; Cole, J.B.; Santana, M.H.A.; Silveira, J.; Mazzoni, G.; Ventura, R.V.; Júnior, M.L.S.; Kadarmideen, H.N.; Garrick, D.J.; et al. Genomic study and Medical Subject Headings enrichment analysis of early pregnancy rate and antral follicle numbers in Nelore heifers. J. Anim. Sci. 2017, 95, 4796. [CrossRef]

55. Ireland, J.L.H.; Scheetz, D.; Jimenez-Krassel, F.; Themmen, A.P.N.; Ward, F.; Lonergan, P.; Smith, G.W.; Perez, G.I.; Evans, A.C.O.; Ireland, J.J. Antral Follicle Count Reliably Predicts Number of Morphologically Healthy Oocytes and Follicles in Ovaries of Young Adult Cattle1. Biol. Reprod. 2008, 79, 1219-1225. [CrossRef]

56. Shembekar, C.A.; Upadhye, J.J.; Shembekar, M.C.; Welekar, S.H. Anti-Mullerian hormone (AMH) as predictor of ovarian reserve. Int. J. Reprod. Contracept. Obstet. Gynecol. 2017, 6, 4006-4010. [CrossRef]

57. Coles, C.A.; Wadeson, J.; Knight, M.I.; Cafe, L.M.; Johns, W.H.; White, J.D.; Greenwood, P.L.; Mcdonagh, M.B. A disintegrin and metalloprotease-12 is type I myofiber specific in Bos taurus and Bos indicus cattle. J. Anim. Sci. 2014, 92, 1473-1483. [CrossRef] [PubMed]

58. Kim, Y.M.; Kim, J.; Heo, S.C.; Shin, S.H.; Do, E.K.; Suh, D.S.; Kim, K.H.; Yoon, M.S.; Lee, T.G.; Kim, J.H. Proteomic identification of adam 12 as a regulator for tgf- $\beta 1$-induced differentiation of human mesenchymal stem cells to smooth muscle cells. PLoS ONE 2012, 7, e40820. [CrossRef] [PubMed]

59. Knight, P.G.; Glister, C. TGF- $\beta$ superfamily members and ovarian follicle development. Reproduction 2006, 132, 191-206. [CrossRef]

60. Feng, L.; Wang, Y.; Cai, H.; Sun, G.; Niu, W.; Xin, Q.; Tang, X.; Zhang, J.; Wang, C.; Zhang, H.; et al. ADAM10-Notch signaling governs the recruitment of ovarian pregranulosa cells and controls folliculogenesis in mice. J. Cell Sci. 2016, 129, 2202-2212. [CrossRef]

61. Russell, D.L.; Brown, H.M.; Dunning, K.R. ADAMTS proteases in fertility. Matrix Biol. 2015, 44-46, 54-63. [CrossRef]

62. Klein, T.; Bischoff, R. Active metalloproteases of the a disintegrin and metalloprotease (ADAM) family: Biological function and structure. J. Proteome Res. 2011, 10, 17-33. [CrossRef]

63. Beck, A.R.P.; Miller, I.J.; Anderson, P.; Streuli, M. RNA-binding protein TIAR is essential for primordial germ cell development. Proc. Natl. Acad. Sci. USA 1998, 95, 2331-2336. [CrossRef]

64. Carbon, S.; Ireland, A.; Mungall, C.J.; Shu, S.; Marshall, B.; Lewis, S.; Lomax, J.; Mungall, C.; Hitz, B.; Balakrishnan, R.; et al. AmiGO: Online access to ontology and annotation data. Bioinformatics 2009, 25, 288-289. [CrossRef]

65. Racedo, S.E.; Wrenzycki, C.; Lepikhov, K.; Salamone, D.; Walter, J.; Niemann, H. Epigenetic modifications and related mRNA expression during bovine oocyte in vitro maturation. Reprod. Fertil. Dev. 2009, 21, 738-748. [CrossRef] [PubMed] 
66. Funston, R.N.; Summers, A.F. Epigenetics: Setting Up Lifetime Production of Beef Cows by Managing Nutrition. Annu. Rev. Anim. Biosci. 2013, 1, 339-363. [CrossRef] [PubMed]

67. Fang, L.; Jiang, J.; Li, B.; Zhou, Y.; Freebern, E.; Vanraden, P.M.; Cole, J.B.; Liu, G.E.; Ma, L. Genetic and epigenetic architecture of paternal origin contribute to gestation length in cattle. Commun. Biol. 2019, 2, 1-11. [CrossRef] [PubMed]

68. Thompson, R.P.; Nilsson, E.; Skinner, M.K. Environmental epigenetics and epigenetic inheritance in domestic farm animals. Anim. Reprod. Sci. 2020, 106316. [CrossRef]

69. Simon, C.; Piquette, G.N.; Frances, A.; EL-Danasouri, I.; Irwin, J.C.; Polan, M.L. The Effect of Interleukin-1 Beta (IL-1 Beta) on the Regulation IL-1 Receptor Type I Messenger Ribonucleic Acid and Protein Levels in Cultured Human Endometrial Stromal and Glandular Cells. J. Clin. Endocrinol. Metab. 1994, 78, 675-682. [CrossRef]

70. Comeau, M.R.; Johnson, R.; DuBose, R.F.; Petersen, M.; Gearing, P.; VandenBos, T.; Park, L.; Farrah, T.; Buller, R.M.; Cohen, J.I.; et al. A poxvirus-encoded semaphorin induces cytokine production from monocytes and binds to a novel cellular semaphorin receptor, VESPR. Immunity 1998, 8, 473-482. [CrossRef]

71. Munoz-Suano, A.; Hamilton, A.B.; Betz, A.G. Gimme shelter-The immune system during pregnancy. Immunol. Rev. 2011, 241, 20-38. [CrossRef] [PubMed]

72. Schumacher, A.; Costa, S.D.; Zenclussen, A.C. Endocrine factors modulating immune responses in pregnancy. Front. Immunol. 2014, 5, 1-13. [CrossRef]

73. Stenina-Adognravi, O.; Plow, E.F. Thrombospondin-4 in tissue remodeling. Physiol. Behav. 2019, 176, $139-148$. [CrossRef]

74. Abo-Ismail, M.K.; Lansink, N.; Akanno, E.; Karisa, B.K.; Crowley, J.J.; Moore, S.S.; Bork, E.; Stothard, P.; Basarab, J.A.; Plastow, G.S. Development and validation of a small SNP panel for feed efficiency in beef cattle. J. Anim. Sci. 2018, 96, 375-397. [CrossRef]

75. Liu, Y.; Li, D.; Li, H.; Zhou, X.; Wang, G. A novel SNP of the ATP1A1 gene is associated with heat tolerance traits in dairy cows. Mol. Biol. Rep. 2011, 38, 83-88. [CrossRef] [PubMed]

76. Pongpiachan, P.; Rodtian, P.; Ota, K. Effects of tropical climate on reproduction of cross- and purebred Friesian cattle in northern Thailand. Asian-Australas. J. Anim. Sci. 2003, 16, 952-961. [CrossRef]

77. Kashyap, N.; Kumar, P.; Deshmukh, B.; Bhat, S.; Kumar, A.; Chauhan, A.; Bhushan, B.; Singh, G.; Sharma, D. Association of ATP1A1 gene polymorphism with thermotolerance in Tharparkar and Vrindavani cattle. Vet. World 2015, 8, 892-897. [CrossRef]

78. Liu, Y.X.; Xu, C.H.; Gao, T.Y.; Sun, Y. Polymorphisms of the ATP1A1 gene associated with mastitis in dairy cattle. Genet. Mol. Res. 2012, 11, 651-660. [CrossRef] [PubMed]

79. Kyriakis, J.M.; Avruch, J. Mammalian mitogen-activated protein kinase signal transduction pathways activated by stress and inflammation. Physiol. Rev. 2001, 81, 807-869. [CrossRef] [PubMed]

80. Zhang, W.; Liu, H.T. MAPK signal pathways in the regulation of cell proliferation in mammalian cells. Cell Res. 2002, 12, 9-18. [CrossRef]

81. Cowan, K.J.; Storey, K.B. Mitogen-activated protein kinases: New signaling pathways functioning in cellular responses to environmental stress. J. Exp. Biol. 2003, 206, 1107-1115. [CrossRef]

82. Madan, P.; Calder, M.D.; Watson, A.J. Mitogen-activated protein kinase (MAPK) blockade of bovine preimplantation embryogenesis requires inhibition of both p38 and extracellular signal-regulated kinase (ERK) pathways. Reproduction 2005, 130, 41-51. [CrossRef]

83. Mor, A.; Mondal, S.; Reddy, I.J.; Soumya, N.P. Genes regulating maternal recognition of pregnancy in domestic animals: An update. Braz. Arch. Biol. Technol. 2015, 58, 854-863. [CrossRef]

84. Pausch, H.; Flisikowski, K.; Jung, S.; Emmerling, R.; Edel, C.; Go, K. Genome-Wide Association Study Identifies Two Major Loci Affecting Calving Ease and Growth-Related Traits in Cattle. Genetics 2011. [CrossRef]

85. Mcclure, M.C.; Morsci, N.S.; Schnabel, R.D.; Kim, J.W.; Yao, P.; Rolf, M.M.; Mckay, S.D.; Gregg, S.J.; Chapple, R.H.; Northcutt, S.L.; et al. A genome scan for quantitative trait loci influencing carcass, post-natal growth and reproductive traits in commercial Angus cattle. Anim. Genet. 2010, 597-607. [CrossRef] [PubMed]

86. Sahana, G.; Guldbrandtsen, B.; Lund, M.S. Genome-wide association study for calving traits in Danish and Swedish Holstein cattle. J. Dairy Sci. 2011, 94, 479-486. [CrossRef] [PubMed] 
87. Michenet, A.; Barbat, M.; Saintilan, R.; Venot, E.; Phocas, F. Detection of quantitative trait loci for maternal traits using high-density genotypes of Blonde d'Aquitaine beef cattle. BMC Genet. 2016, 17, 1-13. [CrossRef] [PubMed]

88. Thomasen, J.R.; Guldbrandtsen, B.; Sørensen, P.; Thomsen, B.; Lund, M.S. Quantitative trait loci affecting calving traits in Danish Holstein cattle. J. Dairy Sci. 2008, 91, 2098-2105. [CrossRef]

89. Zhang, Z.; Kargo, M.; Liu, A.; Thomasen, J.R.; Pan, Y.; Su, G. Genotype-by-environment interaction of fertility traits in Danish Holstein cattle using a single-step genomic reaction norm model. Heredity 2019, 123, 202-214. [CrossRef]

90. Kiser, J.N.; Keuter, E.M.; Seabury, C.M.; Neupane, M.; Moraes, J.G.N.; Dalton, J.; Burns, G.W.; Spencer, T.E.; Neibergs, H.L. Validation of 46 loci associated with female fertility traits in cattle. BMC Genom. 2019, 20, 1-13. [CrossRef] [PubMed]

91. Irano, N.; Miguel, G.; De Camargo, F.; Costa, R.B.; Paula, A.; Terakado, N.; Fabrícia, A.; Magalh, B.; De, R.M. Genome-Wide Association Study for Indicator Traits of Sexual Precocity in Nellore Cattle. PLoS ONE 2016, 11, e0159502. [CrossRef]

92. Kereilwe, O.; Pandey, K.; Borromeo, V.; Kadokawa, H. Anti-Müllerian hormone receptor type 2 is expressed in gonadotrophs of postpubertal heifers to control gonadotrophin secretion. Reprod. Fertil. Dev. 2018, 30, 1192-1203. [CrossRef]

93. Ilha, G.F.; Rovani, M.T.; Gasperin, B.G.; Ferreira, R.; de Macedo, M.P.; Neto, O.A.; Duggavathi, R.; Bordignon, V.; Gonçalves, P.B.D. Regulation of Anti-Müllerian Hormone and Its Receptor Expression around Follicle Deviation in Cattle. Reprod. Domest. Anim. 2016, 51, 188-194. [CrossRef]

94. Pierucci, J.C.; Tonhati, H.; De Albuquerque, L.G.; Cardoso, D.F.; dos Santos, D.J.; Freitas, A.C.; Barbero, M.M.; De Camargo, G.M.; Braz, C.U.; Gimenes, L.U. Amh Polymorphisms and their association with traits indicative of sexual precocity in Nelore heifers. Semin. Ciências Agrárias 2019, 40, 1489-1500. [CrossRef]

(C) 2020 by the authors. Licensee MDPI, Basel, Switzerland. This article is an open access article distributed under the terms and conditions of the Creative Commons Attribution (CC BY) license (http://creativecommons.org/licenses/by/4.0/). 